\title{
EFFECT OF FOUNDATION FLEXIBILITY ON DYNAMIC BEHAVIOUR OF ASYMMETRIC BUILDING FRAME WITH ISOLATED FOOTING
}

\author{
Praveena $E^{1}$, G Narayana $^{2}$ \\ ${ }^{1}$ Post graduate student, Dept. of civil Engineering, SJCIT, Chickaballapur, Karnataka, India \\ ${ }^{2}$ Professor\& Head of the department, Dept. of civil engineering, SJCIT, Chickaballapur, Karnataka, India
}

\begin{abstract}
In general the seismic design of building frame structures the designers will consider only the results of fixed base condition the effect of flexibility is ignored. In post-earthquake study the framed structure reveals that the interaction of soil and foundation plays an important role in damage of the building frame structures. In this regard a literature survey has been done on frame structures supported on various foundations such as isolated, combined, raft \& pile foundations. To examine the literature revels the few investigations were done on asymmetric building frame structure is supported on isolated footing. So in this paper is an attempt to the study of dynamic behavior of asymmetric building frame structure is supported on isolated footings. The modeling and analysis is done by using "finite element method software" SAP2000 VERSION 14, by considering the different soil conditions, (soft, medium, hard) different soil parameters (passion's ratio, young's modulus, dynamic shear modulus) different height ratio's, different span ratio's \& fixed base conditions. The response of the building frame structure is obtained in terms of fundamental natural period, lateral displacement and seismic base shear.
\end{abstract}

Keywords: Soil structure interaction, Fundamental natural period, Base shear, Lateral displacement....

\section{INTRODUCTION}

Soil structure interaction is a most important criterion for design of building frame structure. Most of the civil engineering structure involves some type of structural elements are directly contact with ground, when the external forces, such as earthquake, vibrations, wind, acts on this system neither the ground displacement or nor the structural displacement are independent of each other. The process in which the response of the soil influences the motion of the structure and the motion of the structure will influences the response of soil is known as "soil structure interaction". In common design practice for dynamic loading assumes the asymmetric building frame structure is to be fixed at their bases. When the load coming from the structure is transfer to the footings then transfer to the hard soil strata, this assumption is applicable only when super structure is more flexible then the hard soil strata, then the reversal is true, when the response of the super structure will also influenced moment in soil to some extent.

\section{MODELING AND ANALYSIS METHODS}

The modeling is done by using FEM software SAP2000 version14, in interaction analysis super structure is considered as 3D space frame including columns and beams in each storey slab at each floor levels. Isolated footing and soil is modeled as a single unit, the soil is considered as a homogeneous, isotropic and elastic half space medium with different input data, such as, dynamic shear modulus and Poisson's ratio. The soil medium beneath the isolated footing as modeled as an eight nodded solid element having a three degree of freedom of translation each in the respective coordinates at each node, the finite element mesh is generated at the aspect ratio is in between 1.25 to 1.5.when the plan and depth of the soil is considered as per BOUSSINESQ'S equation, the plan of the soil is taken as a 1.5 to 2.0times of the width of the footing and depth of the soil is taken as 2.5times of the width of the footing. The flexible floor diaphragm for each slab is modeled as thin shell with four noded plate element with four degree of freedom system at each node such as three translational and three rotations in their respective co-ordinates. The dynamic response spectrum analysis is done as per IS1893:2000 when the structure is modeled as fixed and flexible base conditions using SAP V14 software package.

\subsection{Soil Parameter and Building Design Input Data for the Present Study with Isolated Footing}

According to Bowles $\mathbf{J} \mathbf{E}$ and Based on dynamic shear modulus soil is classified as hard, medium, soft, by using various parameters as shown below.

Table-1: Soil parameters

\begin{tabular}{|l|l|l|l|l|}
\hline $\begin{array}{l}\text { S1 } \\
\text { no }\end{array}$ & Type of soil & $\begin{array}{l}\text { Shear } \\
\text { modulus } \\
(\mathrm{G}) \mathrm{KN} / \mathrm{m}^{2}\end{array}$ & $\begin{array}{l}\text { Elastic } \\
\text { modulus } \\
(\mathrm{E}) \mathrm{KN} / \mathrm{m}^{2}\end{array}$ & $\begin{array}{l}\text { Poisson } \\
\text { 's ratio } \\
(\mu)\end{array}$ \\
\hline 1 & Hard(Type-1) & 30,000 & 72,000 & 0.2 \\
\hline 2 & $\begin{array}{l}\text { Medium(Typ } \\
\text { e-2) }\end{array}$ & 20,000 & 50,000 & 0.25 \\
\hline 3 & Soft(Type-3) & 10,000 & 26,000 & 0.3 \\
\hline
\end{tabular}


The members properties are Column size: $350 \mathrm{mmX} 500 \mathrm{~mm}$

Material properties are Grade of concrete: M25 Beam size: $250 \mathrm{mmX600mm}$, Young's modulus: $25 \times 10^{6}$ $\mathrm{KN} / \mathrm{m}^{2}$

Thickens of slab: $150 \mathrm{~mm}$, Density of concrete: $25 \mathrm{KN} / \mathrm{m}^{3}$ Earthquake live load on slab, Density of brick masonry: 20 $\mathrm{KN} / \mathrm{m}^{3}$
Roof: $0.25 \times 1.5=0.375 \mathrm{KN} / \mathrm{m}^{2}$

Seismic data

Seismic Zone: V

Zone factor: 1

Response Reduction factor: 5 Floor: $0.25 X 3.0=0.75 \mathrm{KN} / \mathrm{m}^{2}$
Load intensities are Floor dead: $1.0 \mathrm{KN} / \mathrm{m}^{2}$ Roof dead: $2.0 \mathrm{KN} / \mathrm{m}^{2}$ Floor live: $3.0 \mathrm{KN} / \mathrm{m}^{2}$ Roof live: $1.5 \mathrm{KN} / \mathrm{m}^{2}$ Critical damping: 0.05
Earthquake loads are consider as per IS 1893:2000(part 1) clause7.3.1, clause7.3.2 and response spectrum data are consider in IS 1893:2000(part 1). For the present study Two bay Two bay six, eight, ten storied moment resting frame with uniform span ratio and height ratio is 1.0 (Height ratio is defined as the ratio of base storey height to upper storey height), and then considered with and without soil flexibility and also analysis is done by considering fixed base and flexible (soil continuum) base conditions.

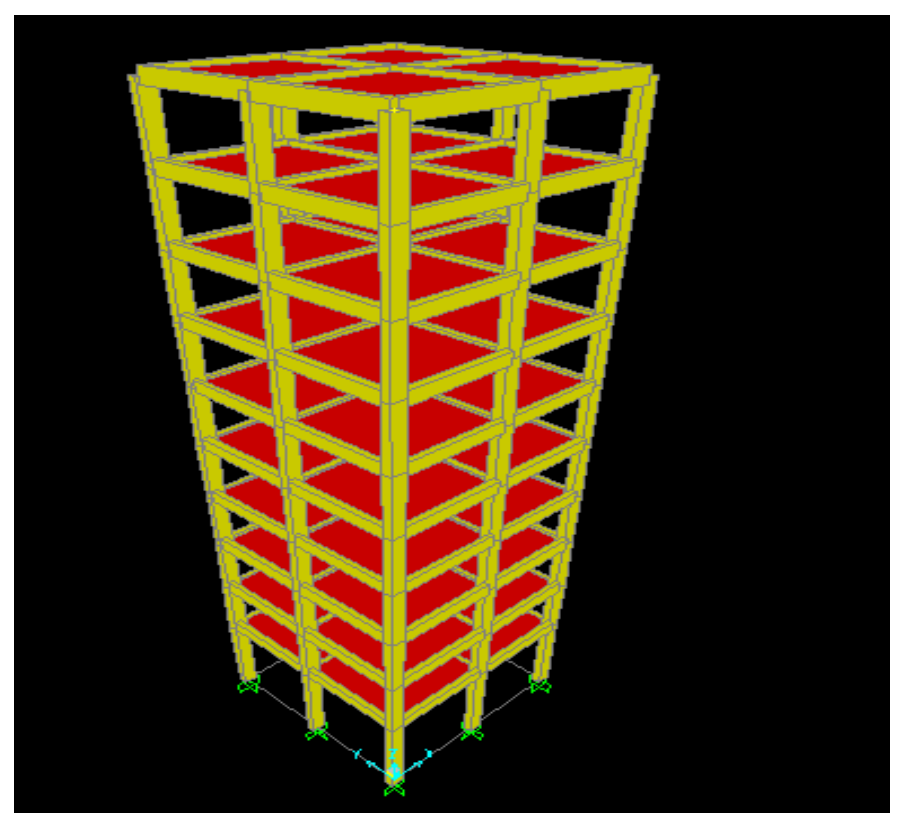

Fig-1: 2X2 10 Storey with Fixed Base Condition

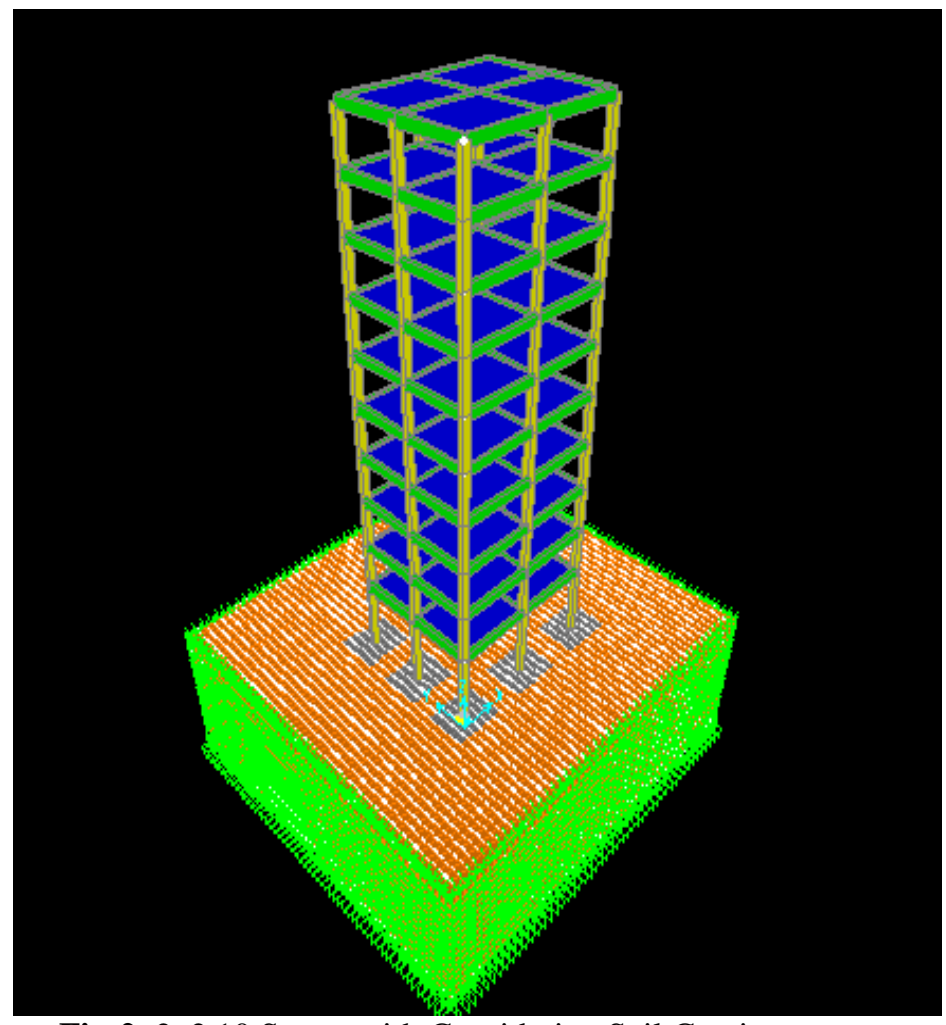

Fig-2: 2x2 10 Storey with Considering Soil Continuum

\section{RESULTS AND DISCUSSION}

The obtained results are Fundamental natural period, Base shear and maximum lateral displacements are comparing Interaction Analysis (IA) and Non-Interaction Analysis (NIA)

\subsection{Fundamental Natural Period (Sec):}

Fundamental natural period variation are considered with shear modulus of three type of soil for zone $\mathrm{V}$ and by considering $\mathrm{Sr}=1.0$ and $\mathrm{Hr}=1.0$ by increasing the number of stories. From table 2: The compression is made by Noninteraction and interaction values of the fundamental natural period of interaction values are less than the Non-interaction values. From the fig 4: Fundamental natural period is increases by increasing the number of stories.

Table-2: Fundamental natural period (sec)

\begin{tabular}{|l|l|l|l|l|l|l|}
\hline \multicolumn{2}{|l|}{ Description } & \multicolumn{2}{l|}{ Base Shear } & $\begin{array}{l}\text { Non - } \\
\text { Intera } \\
\text { stion }\end{array}$ \\
\hline $\begin{array}{l}\text { S } \\
1\end{array}$ & $\begin{array}{l}\text { Frame } \\
\text { Type }\end{array}$ & $\begin{array}{l}\text { IS1893 } \\
: 2002\end{array}$ & Soft & $\begin{array}{l}\text { Medi } \\
\text { um }\end{array}$ & hard \\
\hline 1 & $\begin{array}{l}\text { XX2 6 Zone V } \\
\text { STOREY }\end{array}$ & 0.018 & 0.014 & 0.010 & 0.020 \\
\hline 2 & $\begin{array}{l}\text { 2X2 8 } \\
\text { STOREY }\end{array}$ & Zone V & 0.020 & 0.016 & 0.011 & 0.027 \\
\hline 3 & $\begin{array}{l}\text { 2X2 10 Zne V } \\
\text { STOREY }\end{array}$ & 0.023 & 0.018 & 0.013 & 0.036 \\
\hline
\end{tabular}




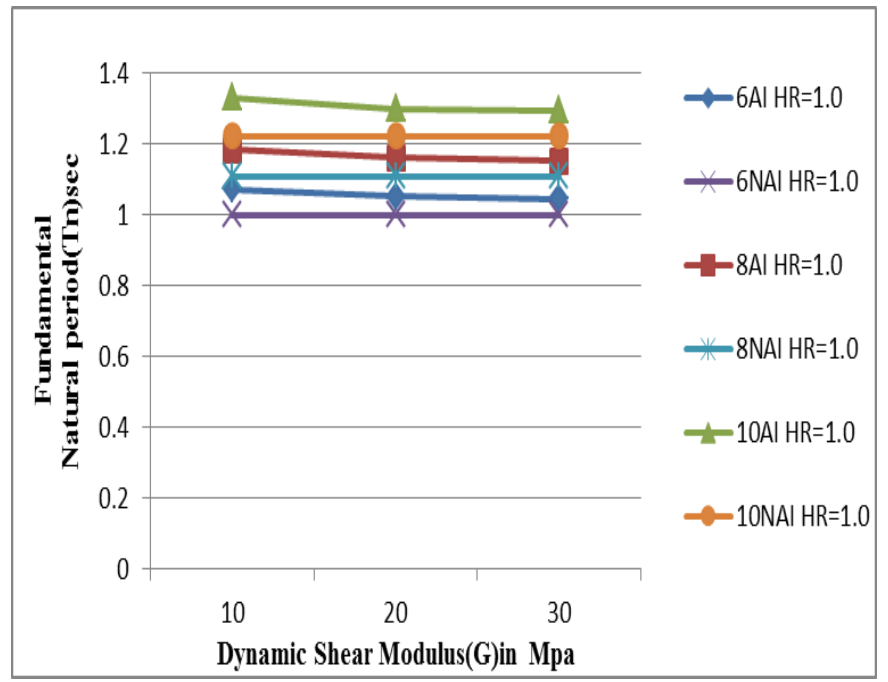

Fig-3: Variation of Fundamental natural period with Shear Modulus

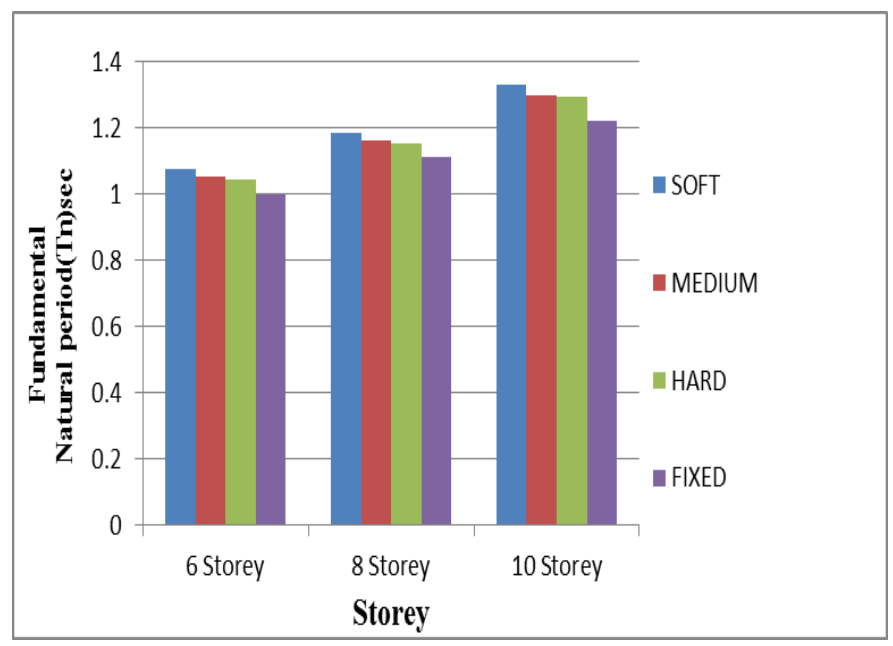

Fig-4: Variation of Fundamental natural period with storey variation for different type of soil and fixed base condition

\subsection{Base Shear}

Base shear variation are considered with shear modulus of three type of soil for zone $\mathrm{V}$ and by considering $\mathrm{Sr}=1.0$ and $\mathrm{Hr}=1.0$ by increasing the number of stories from table 3 : base shear is decreases by increasing the stiffness of the soil and storey height increases by decreasing the base shear. From Fig 6: Base shear is increases by increasing the number of stories.

Table-3: Base shear $(\mathrm{KN})$

\begin{tabular}{|l|l|l|l|l|l|l|}
\hline \multicolumn{2}{|l|}{ Description } & \multicolumn{3}{l|}{ Base Shear } & $\begin{array}{l}\text { Non - } \\
\text { Interac } \\
\text { tion }\end{array}$ \\
\hline S1 & $\begin{array}{l}\text { Frame } \\
\text { Type }\end{array}$ & $\begin{array}{l}\text { IS189 } \\
3: 200 \\
2\end{array}$ & Soft & $\begin{array}{l}\text { Mediu } \\
\mathrm{m}\end{array}$ & hard & \\
\hline 1 & $\begin{array}{l}2 \text { X2 6 } \\
\text { STOREY }\end{array}$ & $\begin{array}{l}\text { Zone } \\
\text { V }\end{array}$ & 1084.4 & 906.3 & $\begin{array}{l}674 . \\
7\end{array}$ & 674.5 \\
\hline 2 & $\begin{array}{l}\text { 2X2 8 } \\
\text { STOREY }\end{array}$ & $\begin{array}{l}\text { Zone } \\
\text { V }\end{array}$ & 1271.9 & $\begin{array}{l}1060 . \\
3\end{array}$ & $\begin{array}{l}790 . \\
6\end{array}$ & 668.9 \\
\hline 3 & $\begin{array}{l}\text { 2X2 10 } \\
\text { STOREY }\end{array}$ & $\begin{array}{l}\text { Zone } \\
\text { V }\end{array}$ & 1407.7 & $\begin{array}{l}1175 . \\
8\end{array}$ & $\begin{array}{l}860 . \\
5\end{array}$ & 659.1 \\
\hline
\end{tabular}

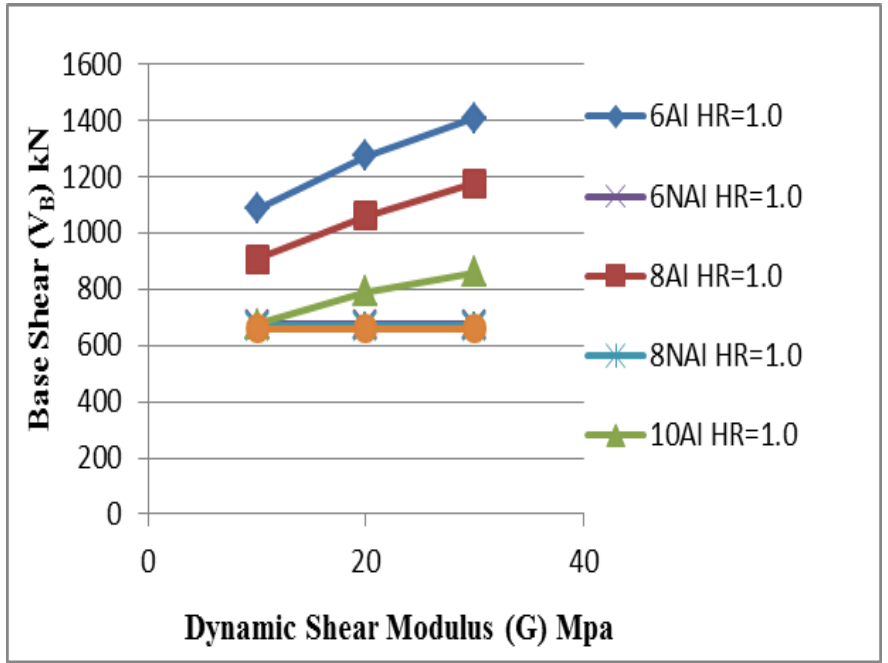

Fig-5: Variation of Base shear with Shear Modulus

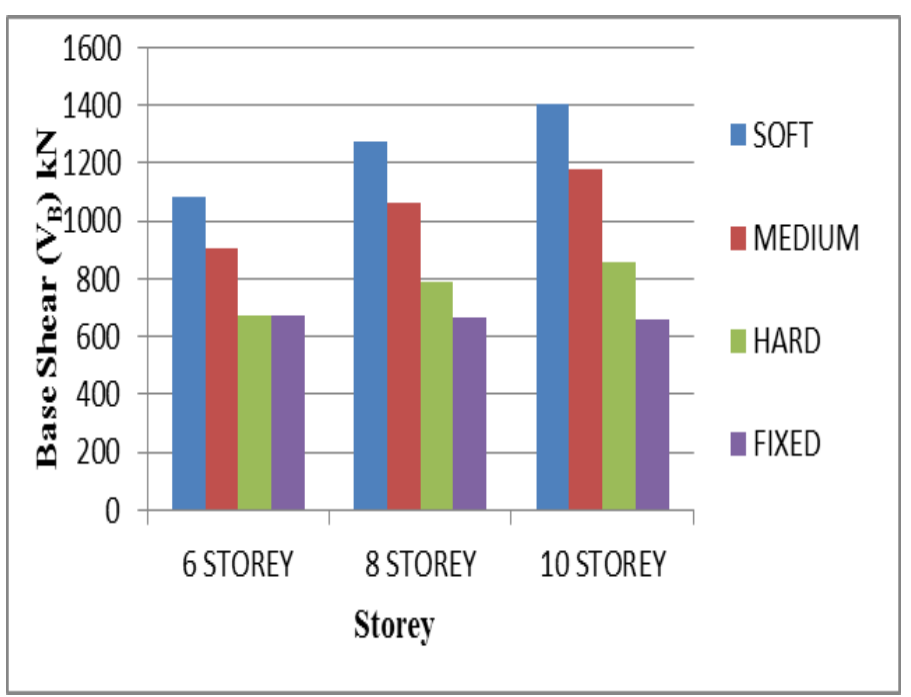

Fig-6: Variation of Base shear with storey variation for different type of soil and fixed base condition

\subsection{Maximum Lateral Displacement}

Maximum lateral displacement variations are considered with shear modulus of three type of soil for zone $\mathrm{V}$ and by considering $\mathrm{Sr}=1.0$ and $\mathrm{Hr}=1.0$ by increasing the number of stories from table 4: Base shear is decreases by increasing the stiffness of the soil, the maximum value will show in fixed base condition. From fig 8: Maximum lateral displacement is increases by increasing the number of stories.

Table-4: Maximum lateral displacement (mm)

\begin{tabular}{|c|c|c|c|c|c|c|}
\hline \multicolumn{3}{|c|}{ Description } & \multicolumn{3}{|c|}{ Base Shear } & \multirow{2}{*}{$\begin{array}{l}\text { Non - } \\
\text { Inter } \\
\text { actio } \\
n\end{array}$} \\
\hline $\begin{array}{l}\mathrm{S} \\
1\end{array}$ & $\begin{array}{l}\text { Frame } \\
\text { Type }\end{array}$ & $\begin{array}{l}\text { IS189 } \\
3: 200 \\
2\end{array}$ & Soft & $\begin{array}{l}\text { Medi } \\
\text { um }\end{array}$ & Hard & \\
\hline 1 & $\begin{array}{l}\text { 2X2 } 6 \\
\text { STOREY }\end{array}$ & $\begin{array}{l}\text { Zone } \\
\text { V }\end{array}$ & 0.018 & 0.014 & 0.010 & 0.020 \\
\hline 2 & $\begin{array}{l}\text { 2X2 } \\
\text { STOREY }\end{array}$ & $\begin{array}{l}\text { Zone } \\
\text { V }\end{array}$ & 0.020 & 0.016 & 0.011 & 0.027 \\
\hline 3 & $\begin{array}{l}2 \mathrm{X} 210 \\
\text { STOREY }\end{array}$ & $\begin{array}{l}\text { Zone } \\
\mathrm{V}\end{array}$ & 0.023 & 0.018 & 0.013 & 0.036 \\
\hline
\end{tabular}




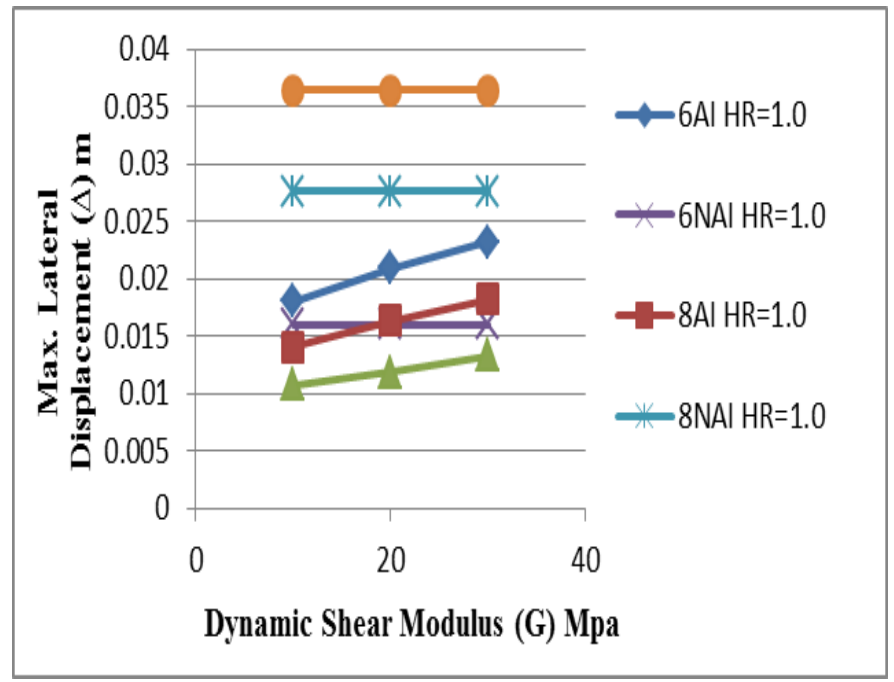

Fig-7: Variation of Maximum lateral displacement with Shear Modulus

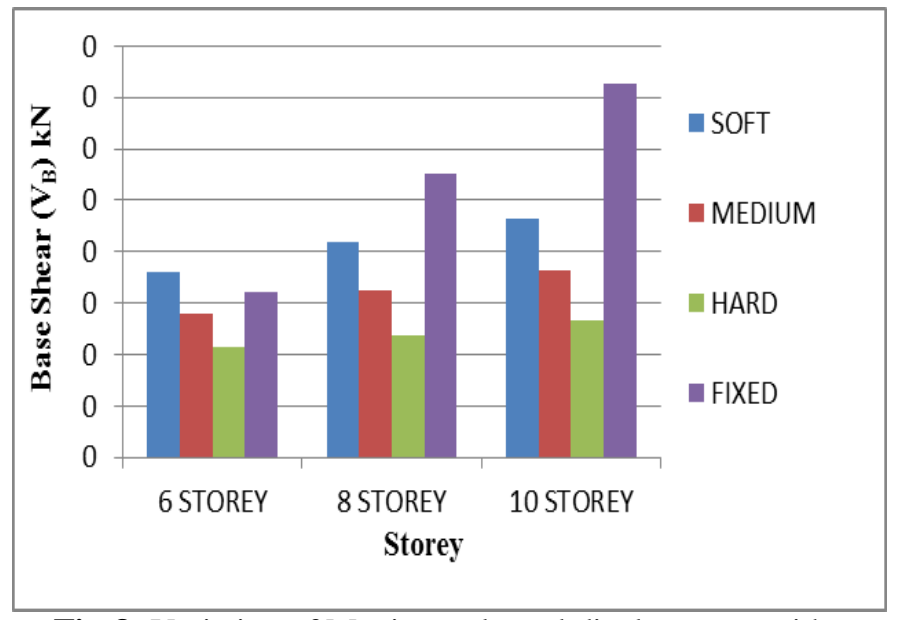

Fig-8: Variation of Maximum lateral displacement with storey variation for different type of soil and fixed base condition

\section{CONCLUSION}

In present the effect of soil flexibility on dynamic behavior of asymmetric building frame resting on isolated footing, such as fundamental natural period, base shear and maximum lateral displacement. First number of stories increases by increasing the fundamental natural period and the noninteraction analysis values are slightly lesser then its interaction analysis values. Second number of stories increases by increasing the base shear values and the noninteraction analysis values less as compared to interaction analysis values. Third also number of stories increases by increasing the displacement values and the maximum lateral displacement is obtained in non-interaction analysis.

\section{ACKNOWLEDGEMENTS}

My humble and heart-felt thanks to my guide Dr. G Narayana professor and head of the department. Department of civil engineering, S J C Institute of Technology. Chickaballapur. Thanks to my dear friends who have supported me to complete this work.

\section{REFERNCES}

[1]. Dr. G Narayana, Dr. H Sharada Bai, \& Mrs. M P Jyothi "Dynamic soil structure interaction behavior of building frame with raft foundation"

[2]. Vivek Garg \& M S Hora "Interaction effect of space frame-strap footing-soil system on forces in super structure" vol.7, No. 11, November 2012.

[3]. Pandey A.D, Prabhat Kumar \& Sharad Sharma "seismic soil- structure interaction of building on hill slope" Volume 2, No 2, 2011.

[4]. Vivek Garg \& M S Hora "A review on interaction behavior of structure-foundation-soil system" Vol.2, Issue 6, November-December 2012.

[5]. IS1893-2002(Part-1), Criteria for Earthquake Resistance Design of structures, Bureau of Indian Standard, New Delhi.

[6]. IS:456:2000, "Code of Practice for Plain \& Reinforced Concrete" Bureau of Indian Standard, New Delhi, India

[7]. Bowles J E. "Foundation Analysis and Design" 5th Edition, McGraw-Hill International Editions, Civil Engineering Series, New York, 1996

\section{BIOGRAPHIES}

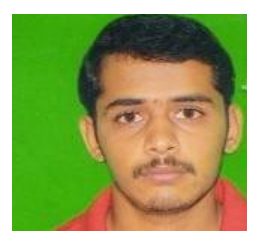

I am Praveena $\mathbf{E}$ in pushing my master of technology in structural engineering from S J C Institute of technology, Chickaballapur. I have one year experience as a site engineer. I am doing my dissertation work under the guidance of Dr. G Narayana. I have pushed my B E, civil engineering from S L N college of engineering, Raichur.

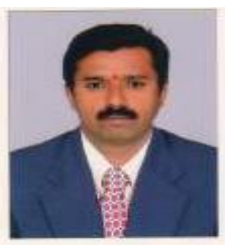

He Mr. Dr. G Narayana, Professor and Head of Department, Department of civil Engineering. S J C Institute of Technology, Chickaballapur. He has wide experience in teaching \& research in the field of structural engineering, He also a structural designer consultant for many project. 